Thread 2: Layers of war and conflict: sightings and soundings

\title{
A migrant and her two-year-old daughter in Tijuana
}

Author: Jenny Edkins $\square$, University of Manchester, UK

Jenny Edkins teaches global politics at the University of Manchester. Her poems have appeared in Acumen, Contexto Internacional, Planet and the anthology Inspirations: poems inspired by the poetry of R.S.Thomas (Einion Books, 2019). Her latest academic book is Change and the politics of certainty (2019). Among her other monographs are studies of famine aid, trauma and memory, face politics, and what happens when people are missing or disappeared.

\section{Abstract}

The poem responds to a photograph by Ilana Panich-Linsman that appeared in the magazine Mother Jones. It depicts a migrant, Arlen Cruz, holding her two year-old daughter as rain soaks the camp at a sports complex in Tijuana, Mexico, where many migrants in the caravan from Central America had been staying for two weeks.

Keywords: Poetry; photography; migrants; camps; Central America; Tijuana; Mexico; motherhood 
A migrant and her two-year-old daughter in Tijuana Jenny Edkins

You turn the page and there she is holding an infant close to her heart, head on her shoulder, asleep.

You've held a child of your own like this his two-year-old body heavy, his hair tousled as you carried him up to bed.

You see her hand gentle round the child a fierce strength behind the numbness in her eyes: she will guard this with her life.

You're too far away and she's just an image arrested in her flight and photographed: flesh and blood made spectacle.

You close the page and leave her there:

a single steadfast young woman holding the world in her arms. 


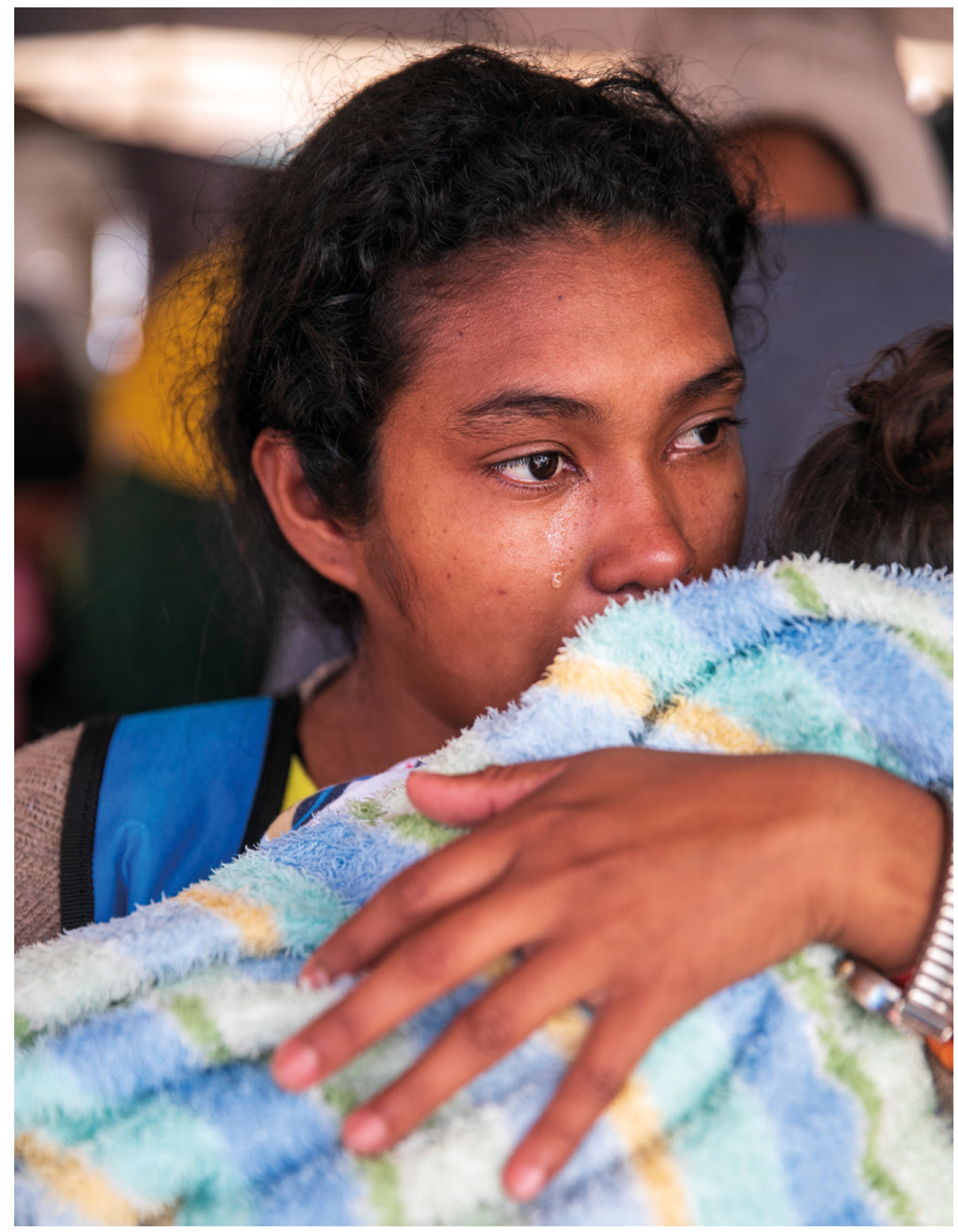

Arlen Cruz holds her two-year-old daughter as rain soaks the camp where many migrants in the caravan from Central America have been staying for two weeks now. Tijuana, Mexico. 29 November 2018. Ilana Panich-Linsman/REDUX.

The photograph appeared under the caption 'A migrant and her two-year-old daughter in Tijuana', in Echavarri, F. (2019) 'The real border emergency', Mother Jones, 44 (3), pp. 9-11. 